\title{
The Impact of Biochar Application on Soil Properties and Plant Growth of Pot Grown Lettuce (Lactuca sativa) and Cabbage (Brassica chinensis)
}

\author{
Sarah Carter ${ }^{1, *}$, Simon Shackley ${ }^{1}$, Saran Sohi ${ }^{1}$, Tan Boun Suy ${ }^{2}$ and Stephan Haefele ${ }^{3}$
}

1 University of Edinburgh, UK Biochar Research Centre, School of GeoSciences, Edinburgh, EH9 3JN, UK; E-Mails: simon.shackley@ed.ac.uk (S.S.); saran.sohi@ed.ac.uk (S.S.)

2 Authority for the Protection and Management of Angkor and the Region of Siem Reap (APSARA), ANGKOR COEX Compound, Apsara Road, Siem Reap, Cambodia;

E-Mail: tanbounsuy@yahoo.com

3 Australian Centre for Plant Functional Genomics, University of Adelaide, 5064 South Australia, Australia; E-Mail: stephan.haefele@acpfg.com.au

* Author to whom correspondence should be addressed; E-Mail: sarah.carter.uk@gmail.com; Tel.: 0031317485133 ; Fax: 0031317419000.

Received: 18 February 2013; in revised form: 26 April 2013 / Accepted: 26 April 2013 /

Published: 7 May 2013

\begin{abstract}
The effect of rice-husk char (potentially biochar) application on the growth of transplanted lettuce (Lactuca sativa) and Chinese cabbage (Brassica chinensis) was assessed in a pot experiment over a three crop (lettuce-cabbage-lettuce) cycle in Cambodia. The biochar was the by-product of a rice-husk gasification unit and consisted of $28.7 \%$ carbon (C) by mass. Biochar application rates to potting medium of 25,50 and $150 \mathrm{~g} \mathrm{~kg}^{-1}$ were used with and without locally available fertilizers (a mixture of compost, liquid compost and lake sediment). The rice-husk biochar used was slightly alkaline ( $\mathrm{pH} 7.79$ ), increased the $\mathrm{pH}$ of the soil, and contained elevated levels of some trace metals and exchangeable cations ( $\mathrm{K}, \mathrm{Ca}$ and $\mathrm{Mg}$ ) in comparison to the soil. The biochar treatments were found to increase the final biomass, root biomass, plant height and number of leaves in all the cropping cycles in comparison to no biochar treatments. The greatest biomass increase due to biochar additions (903\%) was found in the soils without fertilization, rather than fertilized soils (483\% with the same biochar application as in the "without fertilization" case). Over the cropping cycles the impact was reduced; a 363\% increase in biomass was observed in the third lettuce cycle.
\end{abstract}


Keywords: Brassica chinensis; compost; crop yield; Lactuca sativa; rice husk char; sandy soil

\section{Introduction}

Rice-husk char (RHC) is a waste by-product of gasification and, due to an absence of demonstrated use for the RHC, lack of knowledge of the properties of the char, and the lack of enforcement of waste management regulations, the material tends to accumulate adjacent to the gasification units [1]. There has been increasing interest in finding appropriate uses of such $\mathrm{RCH}$ [2], and the purpose of this research was to explore the potential of RHC as a form of biochar with attendant benefits when introduced into agricultural soils. The study explores the impact of biochar over time on a multiple cycle pot trial, using two different vegetable crops. Due to large amounts of available RHC accumulating around rice mills (and small industrial installations that use rice husk gasification as a power supply, e.g. ice-making factories) in rural rice-growing areas of Cambodia [1], it is not surprising that RHC is already applied albeit locally in an agricultural context. Currently, little research is available on the agronomic impacts of RHC, with two published studies for impacts on rice productivity in Cambodia [3,4] suggesting that yield increases of 30 to $40 \%$ are feasible with 30 to $41.5 \mathrm{Mg} \mathrm{ha}^{-1} \mathrm{RHC}$ application levels. Impacts of RHC on vegetable productivity are not presently known, nor are the effects of high application rates in a vegetable-growing scenario. Some previous research suggests that the greatest positive effect of biochar is seen at an application rate of $100 \mathrm{Mg} \mathrm{ha}^{-1}$ [4], and that biochar application of up to $140 \mathrm{Mg} \mathrm{ha}^{-1}$ on weathered soils in the tropic resulted in improved crop yields relative to the control [5]. On the other hand, some studies indicate yields decrease (relative to the control) if too much biochar is added to soil [6,7]. One of the purposes of the study reported here was to test the growth pattern of vegetables at high levels of RHC in pots in order to ascertain whether an upper application-threshold became evident beyond which further RHC addition, alongside other soil amendments, becomes counter-productive. In Cambodia, compost and liquid composts are routinely used to add organic matter and nutrients to soil, while soil additives such as locally-branded "effective microorganisms" (EM), are also commonly used. In the Siem Reap province of Cambodia, lake sediment is deposited seasonally from the Tonle Sap Lake and is considered to enhance crop growth in agricultural land [8]. Following common practice and locally available resources, we tested the impact of RHC and RHC with combinations of these other soil amendments.

RHC shares some of the characteristics of biochar, which has been defined as the porous carbonaceous solid produced by thermochemical conversion (usually slow pyrolysis) suitable for the safe and long-term storage of carbon [9]. Because of their high ash content ( $c a .60 \%$ to $70 \%$ on account of the active uptake of silicon in rice [1]) and relatively low carbon content ( $\mathrm{ca}$. 30\% to $35 \%$ [1]), gasification chars are not automatically categorized as 'biochar'. The RHC meets the requirement of the International Biochar Initiative (IBI) [10] that the molar $\mathrm{H}$ to organic $\mathrm{C}$ ratio should have a maximum value of 0.7 [1]. The IBI defines three classes of biochar, and RHC would qualify under its guidelines as either Class 2 ( $\geq 30 \%$ and $<60 \%$ organic carbon) or Class $3(\geq 10 \%$ and $<30 \%$ organic carbon) [10]. The European Biochar Certificate (EBC) [11], on the other hand, states that biochar must have a minimum of 50\% stabile organic carbon; hence the RHC could not be classified as 
a biochar, but could be termed a "carbon-rich gasification ash". Another way of defining biochar is to consider the percentage of carbon conserved within the char residue from the feedstock. This is in line with the rationale for biochar for carbon capture and storage. In this case, given that slow pyrolysis results in a figure of $c a .50 \%$ conservation, using a definition of half of this at $25 \%$ carbon conversion, RHC would qualify as a biochar and we regard it as such for the purposes of this paper, while acknowledging the continuing lack of consensus internationally.

The potential impacts of biochar as a soil amendment have been extensively reviewed in the literature, e.g. Sohi et al. [12] and Jeffery et al. [13]. Biochar may alter the physical properties of the soil, including increasing aeration and water holding capacity of certain soils [12-15]. Biochar can increase $\mathrm{pH}$ by $0.5-1.0$ unit in most cases for application rates of $30 \mathrm{Mg} \mathrm{ha}^{-1}$ of biochar [16], nutrients are directly available through the solubilization of ash in the solid biochar residue and other nutrients may become available though microbial utilization of a small labile carbon component of biochar [8]. Gasification chars typically contain more nutrients, than those produced in slow pyrolysis for example [1]. While "fresh RHC" does not have a very high cation exchange capacity (CEC), it is still higher than weathered sandy tropical soils, and the CEC increases over time in soil $[17,18]$.

Chan et al. [19], Asai et al. [6] and Saarnio et al. [20] show that biochar application in addition to fertilizer addition can lead to plant growth benefits, but a negative effect is sometimes observed without fertilization, due to reduced bio-availability, through sorption of nitrogen [21,22]. In addition, the effect may be short lasting: in Saarnio et al [20] the first trial cycle showed a significant difference in above ground biomass, but further cycles showed no significant differences. The soils in much of Cambodia are Acrisols, with a high sand content often characterized by a subsurface accumulation of low activity clays, a low base saturation and low exchangeable K and Olsen P [23,24]. In sandy soils, aridity is often a threat to agriculture, and low levels of biochar amendment can increase seedling resistance to wilting [25], and can increase water holding capacity (WHC) with additions of only 5\% biochar in mass of top soil [22]. Asai et al. [6] also directly measured the influence of biochar on the WHC in two separate locations in Laos and the saturated hydraulic conductivity (SHC) of the surface soil and the xylem sap flow (XSF) of rice plants. Biochar was shown to have significantly increased the SHC and XSF at both sites, supporting the hypothesis that biochar increases the WHC and water availability to plants [5].

In summary, this paper addresses the proposition that RHC can provide benefits to crop production under the growing conditions prevalent in Cambodia. The findings have implications for subsistence and commercial agriculture in the region, and the sustainable use of available rice husk biochar.

\section{Materials and Methods}

\subsection{Growing Substrates}

Lettuce (Lactuca sativa) and cabbage (Brassica chinensis) were grown consecutively in pots prepared with a non-fertilized soil (0) and a fertilized soil (CS) with the addition of locally available organic fertilizers, namely compost, a liquid compost and lake sediment (quantities are shown in Table 1). Soil was collected from the Government of Cambodia APSARA research farm in Siem Reap. It is unlikely that these soils contain charcoal already since there has not been a tradition of crop 
residue or other burning on the land. The soil was analyzed (Table 2) from soil cores taken at a depth of 0-20 $\mathrm{cm}$ and found to be acidic, relatively low in organic matter, and to have a sandy loam soil texture. Sediment was obtained from the bed of the Tonle Sap lake about $1 \mathrm{~km}$ from the shore. The lake is approximately $20 \mathrm{~km}$ from the research farm. The compost solution was produced by collecting the liquid leachate from waste farm plant matter that had been decomposing for six weeks. The leachate was diluted (to $2 \%$ volume) and used to irrigate the pots three times per day. No other nutrients were subsequently added during the experimental period. The compost was made on farm from cow manure, chicken litter, leaf litter and lime.

Table 1. Treatment description of soil, biochar and local organic fertilizer addition.

\begin{tabular}{|c|c|c|c|c|c|}
\hline Treatment & Name & $\begin{array}{c}\text { Biochar } \\
\left(\mathrm{g} \mathrm{kg}^{-1}\right) \\
\left(\mathrm{Mg} \mathrm{ha}^{-1 *}\right)\end{array}$ & $\begin{array}{c}\text { Lake } \\
\text { sediment } \\
\left(\mathrm{g} \mathrm{kg}^{-1}\right)\end{array}$ & $\begin{array}{l}\text { Compost } \\
\left(\mathrm{g} \mathrm{kg}^{-1}\right)\end{array}$ & $\begin{array}{l}\text { Liquid } \\
\text { compost }\end{array}$ \\
\hline 0 & $\begin{array}{l}\text { Non-fertilized soil without } \\
\text { biochar }\end{array}$ & 0 & 0 & 0 & No \\
\hline $\mathrm{B} 50$ & $\begin{array}{l}\text { Non-fertilized soil with } \\
\text { biochar }\end{array}$ & $50.24(80)$ & 0 & 0 & No \\
\hline $\mathrm{CS}$ & Fertilized soil without biochar & 0 & 12.56 & 25.12 & Yes \\
\hline $\mathrm{CS}+\mathrm{B} 25$ & $\begin{array}{l}\text { Fertilized soil with a low dose } \\
\text { of biochar }\end{array}$ & $25.12(40)$ & 12.56 & 25.12 & Yes \\
\hline $\mathrm{CS}+\mathrm{B} 50$ & $\begin{array}{l}\text { Fertilized soil with a medium } \\
\text { dose of biochar }\end{array}$ & $50.24(80)$ & 12.56 & 25.12 & Yes \\
\hline $\mathrm{CS}+\mathrm{B} 150$ & $\begin{array}{c}\text { Fertilized soil with a high } \\
\text { dose of biochar }\end{array}$ & $150.00(167)$ & 12.56 & 25.12 & Yes \\
\hline
\end{tabular}

Note: * equivalent area based weight (approx.).

The biochar used was the rice-husk char from a $150 \mathrm{~kW}$ capacity continuous feed rice-husk gasification unit at the EAP Sophat ice factory in Kralanh District Town, Siem Reap Province, Cambodia. The gasification unit was manufactured by Ankur Scientific Energy Technologies Pvt. Ltd., Vadodara, India, and operates at temperatures between 900 and $1100{ }^{\circ} \mathrm{C}$.

\subsection{Pot Experiment}

Treatments were set up in slope-sided plastic pots $20 \mathrm{~cm}$ in height and $20 \mathrm{~cm}$ in diameter at the top and $16 \mathrm{~cm}$ at the base. The pots were filled with the growing medium in addition to $200 \mathrm{~g}$ of stones in the base to improve drainage. The substrate (Table 1) components were air dried for $24 \mathrm{~h}$, weighed and crushed finely then mixed thoroughly before lightly packing the pots. The weight of each filled pot was $5000 \mathrm{~g}$. However, owing to the low bulk density of the RHC the weight was only $3500 \mathrm{~g}$ for the treatment with the highest biochar addition $(\mathrm{CS}+\mathrm{B} 150) . \mathrm{Mg} \mathrm{ha}^{-1}$ equivalent values were calculated on a weight per pot surface area $\left(314 \mathrm{~cm}^{2}\right)$ basis. A total of 8 pots were initially established for each treatment which were treated to the same conditions as the other experimental pots in the case that plants died and replacements were needed.

The pots were then arranged in a complete randomized block design. The pots were randomly rotated each day to a different position within the block for the duration of the trial. Each pot was 
provided with $0.25 \mathrm{~L}$ of water, two to three times per day as required depending on the prevailing weather conditions. All pots were stood on raised platforms allowing drainage and a suspended net was used to reduce the sunlight exposure and rain damage to the plants. Weeding and other management practices were undertaken if necessary.

The pots were set up in February 2010 and the final (third) harvest was taken in June 2010. In each cycle, seedlings were grown in the same potting medium (non-fertilized soils without biochar), to encourage germination before being transplanted into the treatment pots. After setting up, pots were left for 13 days before the first lettuce plants were planted into the trial pots. The first cycle of lettuce seed were germinated and grown for a total of 46 days (17 days in seed trays, and 29 days in the treatment pots). After harvesting the first cycle lettuce plants, cabbage were planted 18 days later as the second crop cycle. The cabbage was grown for a total of 30 days ( 9 days in seed trays, and 21 days in the treatment pots). The third cycle was lettuce again, commencing 16 days after the cabbage was harvested. The second lettuce crop was grown for a total of 42 days (14 days in seed trays, and 28 days in the treatment pots).

In the second cropping cycle (cabbage), only one plant survived in the control treatment. The data on this single plant was used out of necessity, and no statistical analysis was carried out using the data from the single specimen, however the data are included in Figure 2 and Table 3.

\subsection{Analysis}

Soil samples (non-fertilized and fertilized) were taken during the experimental set up and were air dried for at least $24 \mathrm{~h}$ and stored cold during transportation. Analysis of both the soil and biochar samples (excluding particle size analysis, and in-situ $\mathrm{pH}$ analysis) was undertaken at the Scottish Environmental Technology Network (SETN) laboratories at University of Strathclyde, UK, using methods also described in Shackley et al. [1] following oven drying. $\mathrm{pH}$ was measured using electrochemical analysis using a ratio of 5:1 in de-ionised water; total $\mathrm{C}, \mathrm{H}, \mathrm{N}$ and $\mathrm{S}$ by dry combustion (CarloErba 1110 CHNS Analyser. Italy); and CEC and exchangeable cations and metals were assessed using $\mathrm{BaCl}_{2}$ according to the British Standard and analysed by inductively coupled plasma optical emission spectrometry (ICP-OES, PerkinElmer Optima 5300 DV, USA). Sixteen polycyclic aromatic hydrocarbons (PAHs), identified as potentially toxic by the US EPA (US Environmental Protection Agency) were analysed after accelerated Solvent Extraction (ASE) using dichloromethane (DCM), quantified using Gas Chromatography-Mass Spectrometry (GC-MS) (ThermoElectron MAT 900, ThermoFisher Scientific, USA). Particle size analysis of the soil was undertaken at Phnom Penh National Agriculture Laboratories, Phnom Penh, Cambodia. Analysis of soil $\mathrm{pH}$ was also undertaken on site in a 1:1 soil water (of $\mathrm{pH}$ 7) solution using a handheld pHep digital unit with a glass electrode (HI98127, Hanna instruments, Kehl am Rhein, Germany). The average of five readings for each treatment was reported, all taken with the handheld $\mathrm{pH}$ unit 75 days after the start of the experiment (between the second and third crop rotations). 
Table 2. Chemical and physical properties of biochar and soil used in the experiment.

\begin{tabular}{|c|c|c|c|c|}
\hline Properties/Analyte & Unit & Soil (0) & $\begin{array}{c}\text { Soil plus local } \\
\text { fertilizers ("CS") }\end{array}$ & Biochar \\
\hline $\mathrm{Ph}$ & $\mathrm{pH}$ unit & 4.77 & 5.39 & 7.79 \\
\hline Total C & $\%$ dry weight & 0.48 & 0.35 & 28.7 \\
\hline Total N & $\%$ dry weight & 0.30 & 0.15 & 0.65 \\
\hline Total S & $\%$ dry weight & 0.00 & 0.00 & $<0.03$ \\
\hline Exchangeable K & $\mathrm{cmol}+\mathrm{kg}^{-1}$ & 1.02 & 1.73 & 36.4 \\
\hline Exchangeable $\mathrm{Na}$ & $\mathrm{cmol}+\mathrm{kg}^{-1}$ & 11.38 & 11.98 & 1.5 \\
\hline Exchangeable $\mathrm{Ca}$ & $\mathrm{cmol}+\mathrm{kg}^{-1}$ & 4.58 & 11.11 & 12.4 \\
\hline Exchangeable Mg & $\mathrm{cmol}+\mathrm{kg}^{-1}$ & 1.70 & 3.09 & 12.8 \\
\hline CEC & $\mathrm{cmol}+\mathrm{kg}^{-1}$ & 18.44 & 24.24 & 44.5 \\
\hline LOI & $\%$ & 2.02 & 6.80 & - \\
\hline $\mathrm{Al}$ & $\mathrm{mg} \mathrm{kg}^{-1}$ & 8929 & 9019 & 92.0 \\
\hline As & $\mathrm{mg} \mathrm{kg}^{-1}$ & $<1.53$ & $<1.63$ & $<1.79$ \\
\hline $\mathrm{Be}$ & $\mathrm{mg} \mathrm{kg}^{-1}$ & $<3.06$ & $<3.26$ & $<3.59$ \\
\hline $\mathrm{Cd}$ & $\mathrm{mg} \mathrm{kg}^{-1}$ & $<0.31$ & $<0.33$ & $<0.36$ \\
\hline $\mathrm{Cr}$ & $\mathrm{mg} \mathrm{kg}^{-1}$ & 11.0 & 10.9 & $<1.44$ \\
\hline $\mathrm{Cu}$ & $\mathrm{mg} \mathrm{kg}^{-1}$ & 2.02 & 2.25 & 8.15 \\
\hline $\mathrm{Fe}$ & $\mathrm{mg} \mathrm{kg}^{-1}$ & 4485 & 4554 & 65.6 \\
\hline $\mathrm{Pb}$ & $\mathrm{mg} \mathrm{kg}^{-1}$ & 5.10 & 5.39 & 2.62 \\
\hline $\mathrm{Mn}$ & $\mathrm{mg} \mathrm{kg}^{-1}$ & 26.3 & 53.4 & 135 \\
\hline $\mathrm{Hg}$ & $\mathrm{mg} \mathrm{kg}^{-1}$ & $<1.53$ & $<1.63$ & $<1.79$ \\
\hline $\mathrm{Ni}$ & $\mathrm{mg} \mathrm{kg}^{-1}$ & 3.48 & 3.92 & $<1.08$ \\
\hline $\mathrm{Si}$ & $\mathrm{mg} \mathrm{kg}^{-1}$ & 79.3 & 92.9 & 66.0 \\
\hline $\mathrm{Ti}$ & $\mathrm{mg} \mathrm{kg}^{-1}$ & 42.4 & 42.9 & 1.79 \\
\hline $\mathrm{Zn}$ & $\mathrm{mg} \mathrm{kg}^{-1}$ & 6.08 & 7.15 & 11.7 \\
\hline $\mathrm{V}$ & $\mathrm{mg} \mathrm{kg}^{-1}$ & 19.0 & 17.9 & $<1.79$ \\
\hline $\mathrm{Ba}$ & $\mathrm{mg} \mathrm{kg}^{-1}$ & 14.9 & 15.4 & 19.3 \\
\hline $\mathrm{Na}$ & $\mathrm{mg} \mathrm{kg}^{-1}$ & 42.3 & 48.5 & 76.1 \\
\hline $\mathrm{Ca}$ & $\mathrm{mg} \mathrm{kg}^{-1}$ & 85.4 & 259 & 609 \\
\hline $\mathrm{Mg}$ & $\mathrm{mg} \mathrm{kg}^{-1}$ & 165 & 226 & 162 \\
\hline $\mathrm{K}$ & $\mathrm{mg} \mathrm{kg}^{-1}$ & 315 & 428 & 595 \\
\hline $\mathrm{Sr}$ & $\mathrm{mg} \mathrm{kg}^{-1}$ & 2.20 & 2.74 & 1.87 \\
\hline B & $\mathrm{mg} \mathrm{kg}^{-1}$ & $<1.49$ & $<1.54$ & 5.83 \\
\hline USEPA 16 PAHs* & $\mathrm{mg} \mathrm{kg}^{-1}$ & - & - & 14.6 \\
\hline Clay $(<0.002$ mm) & $\%$ & 16 & 17 & - \\
\hline Fine silt $(0.002-0.02 \mathrm{~mm})$ & $\%$ & 18 & 22 & - \\
\hline Coarse silt $(0.02-0.05 \mathrm{~mm})$ & $\%$ & 5 & 5 & - \\
\hline Fine sand $(0.05-0.2 \mathrm{~mm})$ & $\%$ & 20 & 26 & - \\
\hline Coarse sand $(0.2-2 \mathrm{~mm})$ & $\%$ & 41 & 30 & - \\
\hline
\end{tabular}

* PAHs were not analysed in the soil since - measurable concentrations were improbable as the site is not known to be contaminated.

For each crop cycle, the following were measured on the date of harvest: above and below ground fresh biomass; plant height measured after harvest from the stem base to the tip of the tallest leaf; and 
the number of leaves. Data were analyzed by a general linear model (GLM) univariate one or two way (when specified) analysis of variance (ANOVA) using SPSS 15.0 (SPSS Inc. Madison, WI, USA). One way ANOVA was followed by post hoc Tamhane's $T 2$ test. Differences are reported as significant at $\rho \leq 0.05$. Standard errors of means are marked as error bars in figures.

\section{Results and Discussion}

\subsection{Soil and Biochar Characterisation}

The $\mathrm{pH}$ of both the non-fertilized soil (0) and the soil with local organic fertilizer (CS) was within typical values for the main rice growing soils in Cambodia that range from $\mathrm{pH} 4$ to 5.9, [8,24] (Table 2). The addition of lake sediment gave the mixture a larger proportion of fine silt and fine sand. The compost and sediment mixture also gave the soil a higher $\mathrm{pH}$, this being raised from $\mathrm{pH} 4.77$ to 5.39. Loss on ignition (LOI) was higher in fertilized soils. The total $\mathrm{C}$ and total $\mathrm{N}$ in the soil with local fertilizers was lower than the non-fertilized soil, which may be due to natural variation in the soil. The biochar had elevated levels of exchangeable $\mathrm{K}, \mathrm{Ca}$ and $\mathrm{Mg}$ and 11 of the 22 trace metals, in comparison to levels of these elements in one of the non biochar-amended soils (Table 2). Certain trace metals may promote plant growth provided that they are below a threshold concentration. However, it is not possible to determine the impact of each individual substrate component, for example each trace metal, upon plant growth from the results presented here; that would require far more extensive further experimentation. In addition, a negative impact on plant growth from an individual substrate component may be counteracted by other positive effects from the biochar addition, for example, an increase in CEC under certain conditions.

The CEC of the biochar was $44.4 \mathrm{cmol} \mathrm{kg}^{-1}$ or double that of the receiving soil. The bulk density of the soil was decreased by approximately one-third with biochar addition of $150 \mathrm{~g} \mathrm{~kg}^{-1}$, assessed by weighing the pot when filled to the same volume either of soil (5000 g) versus soil plus biochar $(3500 \mathrm{~g})$, which is consistent with findings that a $10 \%$ biochar amendment significantly decreased bulk density of the soil [21]. The structure of the soil was also visibly altered, and, anecdotally, uprooting plants in the biochar amended soil was much easier than in the case of the non biochar-amended soil.

The measured $\mathrm{pH}$ of the biochar used in this study (7.79) was lower than other rice husk biochar samples tested from four similar gasification units, which had a mean value of 9.63 [1]; the reason for this difference is not known. Biochar addition increased the mean $\mathrm{pH}$ in both fertilized and non-fertilized soil. In the non-fertilized soil, the addition of biochar ( 0 to $\mathrm{B} 50$ ) increased the $\mathrm{pH}$ by 0.5 units from 4.8 to 5.3 but this was not significant $(\rho=0.095)$. In the fertilized soil with the same rate of biochar addition (CS to CS + B50), there was a significant $\mathrm{pH}$ increase of 0.6 units from 5.5 to 6.1 $(\rho<0.001)$ (Figure 1). The greatest $\mathrm{pH}$ increase was 1.2 units, after addition of $150 \mathrm{~g} \mathrm{~kg}^{-1}$ biochar to fertilized soil (CS + B150). There was a significant difference in the mean $\mathrm{pH}$ of soils amended with varying rates of biochar; the increases in $\mathrm{pH}$ in biochar-amended soils were consistent with increases in $\mathrm{pH}$ reported elsewhere [16]. Low $\mathrm{pH}$ can limit plant growth through modifying the dynamic of crop nutrients, so biochar addition could be particularly beneficial in the acidic soils widespread in Cambodia.

Low concentrations of 16 PAHs $\left(14.6 \mathrm{mg} \mathrm{kg}^{-1}\right)$, were diluted by incorporation into soil. RHC 
samples in other studies had higher PAH contents (up to $104 \mathrm{mg} \mathrm{kg}^{-1}$ ), however risks from contamination after incorporation into the soil were considered low [1], at least compared to those presented by urban soils in the UK (10-100 $\left.\mathrm{mg} \mathrm{kg}^{-1}\right)$ [9]. It should be noted, however, that extracting with toluene has been shown to show higher PAH concentrations than with DCM, albeit still incomplete ( $c a .50 \%$ to $80 \%$ ) due to the high affinity of biochar for PAH compounds [26,27]. In order to understand the impacts of PAH on plant growth, it might also be desirable to assess the concentration of specific PAH compounds, as some studies have shown negative effects on plant growth at concentrations of $2 \mathrm{mg} \mathrm{kg}^{-1}$ [28].

Figure 1. Mean and standard error values for $\mathrm{pH}$ readings in different soil treatments.

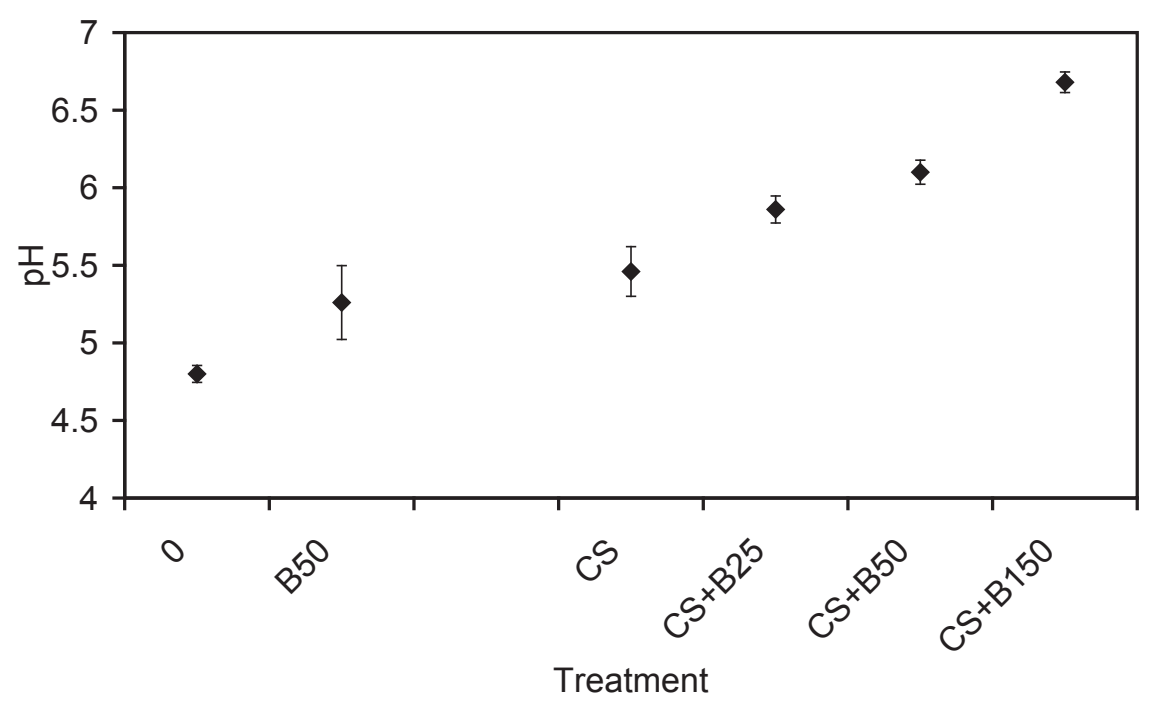

\subsection{Plant Growth Indicators}

For all three cycles of lettuce and cabbage production, above ground biomass increased with biochar addition (Figure 2). The greatest increase relative to the control was $903 \%$, with the addition of $50 \mathrm{~g} \mathrm{~kg}^{-1}$ biochar to non-fertilized soil (Table 3). In each cycle the lowest above ground biomass was from the non-fertilized and non-biochar amended soil (0) and the highest above ground biomass was in the treatment with fertilizer addition and highest level of biochar application (CS + B150). Biochar addition to non-fertilized soils (0) significantly increased all the plant growth indicators for both lettuce trials, except for below ground biomass for the second lettuce crop. In fertilized soils (CS), CS + B50 and CS + B150 showed increases for one or both of the lettuce crops for all plant growth indicators (Figure 2). With the addition of $25 \mathrm{~g} \mathrm{~kg}^{-1}$ biochar to the same soil (CS), no significant increases were seen in the lettuce crop growth indicators. No significant differences were seen for the cabbage crops (Figure 2), in comparison to the equivalent baseline (0 or CS). Significant differences between B50 and CS + B150 for example were not reported in Figure 2. 
Figure 2. Lettuce crop 1, cabbage * and lettuce crop 2 in all treatments values and standard error across all cycles for (a) above ground biomass (g) (b) below ground biomass ( $\mathrm{g}$ ) (c) number of leaves (d) stem length $(\mathrm{cm}) . "$ Significantly different from control "0" (treatment without CS only); ${ }^{\ddagger}$ significantly different from control CS (treatments with CS only) (ANOVA with post hoc Tamhane, $\rho<0.05$ ).
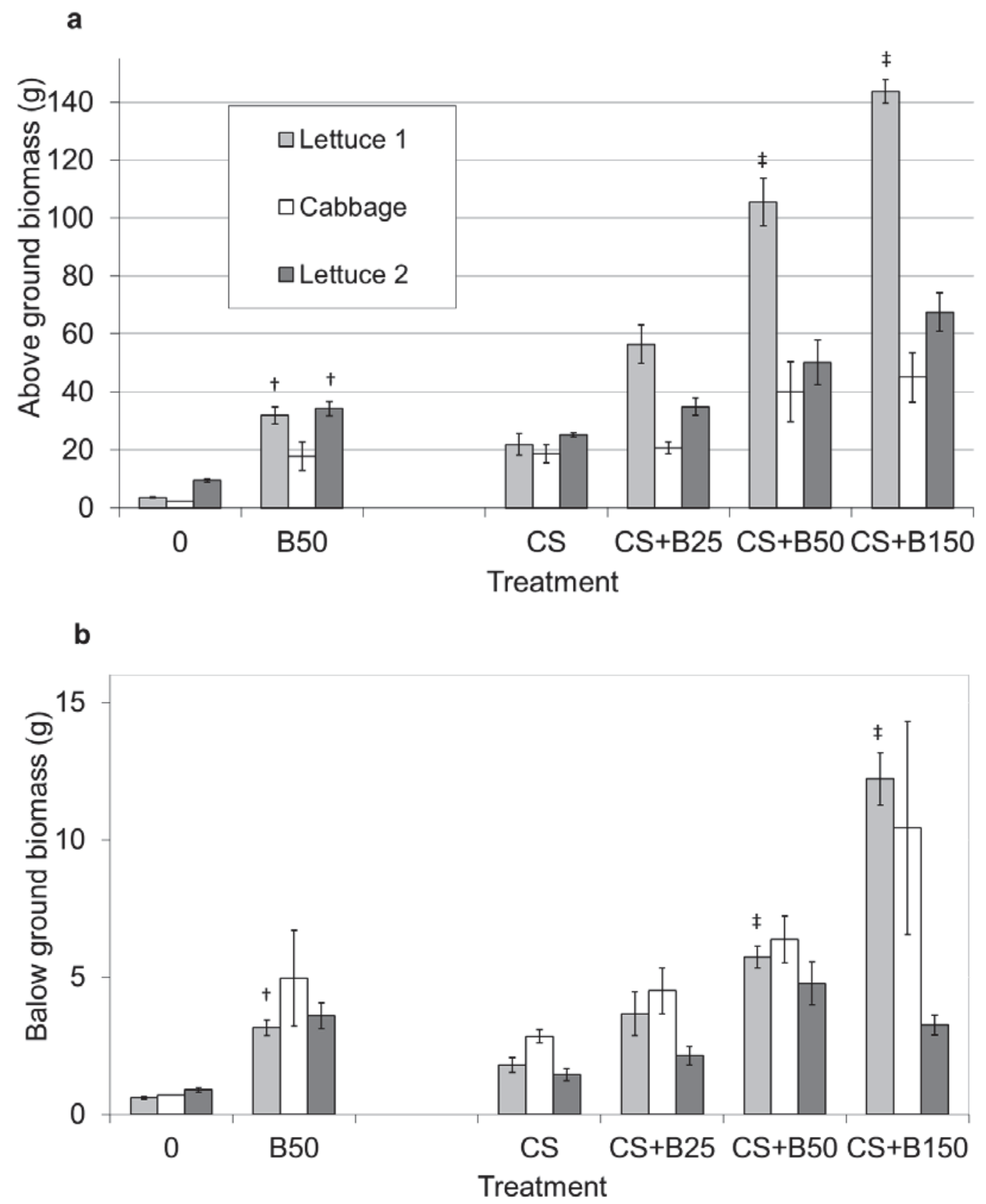
Figure 2. Cont.
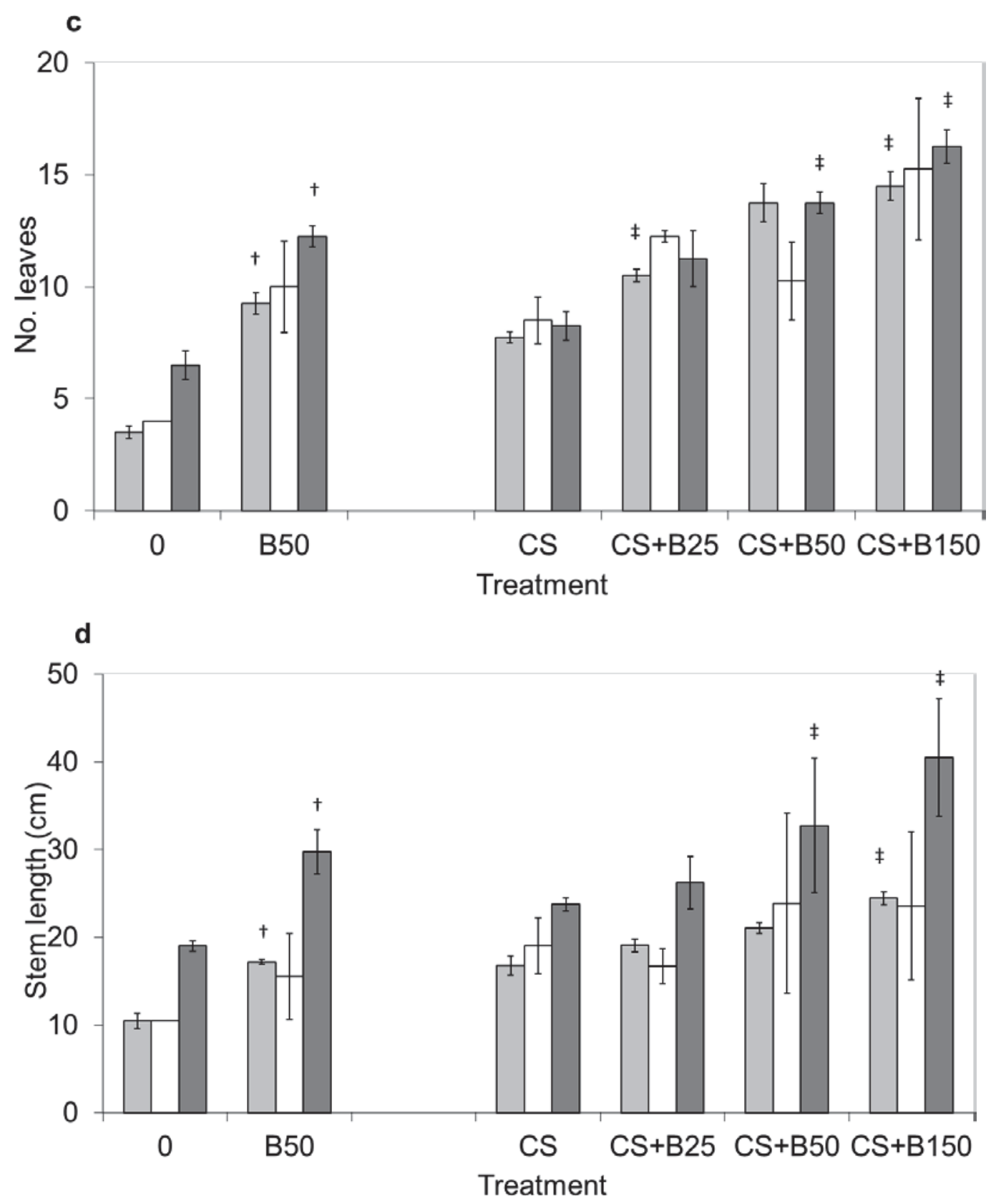

Note: * since there is only one value for " 0 " cabbage, no error bars are included.

The mean number of leaves was higher with biochar addition, in both the treatments with and without the compost-sediment mix, for all three crop cycles. The general trend was for increased below ground biomass with increasing biochar application rate; however, the third crop in CS + B150 was lower than CS + B50; 3.26 g compared with $4.77 \mathrm{~g}$. This may reflect an improved soil physical structure, indeed a reduction of tensile strength and increase in field capacity of hard setting soils with biochar incorporation (which was particularly apparent with biochar additions of $>50 \mathrm{Mg} \mathrm{ha}{ }^{-1}$ ) has been reported elsewhere [19]. The stem length also increased in each cycle with the amount of biochar added to the treatments, apart from a slight decrease in cabbage during the second cycle. 
Table 3. Percentage increase in crop yields (above ground biomass) from biochar addition in all treatments from a baseline scenario of non-fertilized soil (0) and soil fertilized with compost, liquid compost and lake sediment (CS). Note: for treatment " 0 " in cabbage, $n=1$.

\begin{tabular}{|c|c|c|c|}
\hline Crop & $\begin{array}{c}\text { Above ground } \\
\text { biomass } \\
\text { (\% above } \\
\text { baseline) } \\
\end{array}$ & Baseline & Biochar additions \\
\hline Lettuce & 903 & $\begin{array}{l}\text { Non-fertilized soil } \\
\text { without biochar }(0)\end{array}$ & Non-fertilized soil with $50 \mathrm{~g} \mathrm{~kg}^{-1}$ biochar (B50) \\
\hline Lettuce & 259 & \multirow{3}{*}{$\begin{array}{l}\text { Fertilized soil without } \\
\text { biochar (CS) }\end{array}$} & Fertilized soil with $25 \mathrm{~g} \mathrm{~kg}^{-1}$ biochar $(\mathrm{CS}+\mathrm{B} 25)$ \\
\hline Lettuce & 483 & & Fertilized soil with $50 \mathrm{~g} \mathrm{~kg}^{-1}$ biochar $(\mathrm{CS}+\mathrm{B} 50)$ \\
\hline Lettuce & 658 & & Fertilized soil with $150 \mathrm{~g} \mathrm{~kg}^{-1}$ biochar $(\mathrm{CS}+\mathrm{B} 150)$ \\
\hline Cabbage & 750 & $\begin{array}{l}\text { Non-fertilized soil } \\
\text { without biochar }(0)\end{array}$ & Non-fertilized soil with $50 \mathrm{~g} \mathrm{~kg}^{-1}$ biochar (B50) \\
\hline Cabbage & 111 & \multirow{3}{*}{$\begin{array}{l}\text { Fertilized soil without } \\
\text { biochar (CS) }\end{array}$} & Fertilized soil with $25 \mathrm{~g} \mathrm{~kg}^{-1}$ biochar $(\mathrm{CS}+\mathrm{B} 25)$ \\
\hline Cabbage & 214 & & Fertilized soil with $50 \mathrm{~g} \mathrm{~kg}^{-1}$ biochar $(\mathrm{CS}+\mathrm{B} 50)$ \\
\hline Cabbage & 241 & & Fertilized soil with $150 \mathrm{~g} \mathrm{~kg}^{-1}$ biochar $(\mathrm{CS}+\mathrm{B} 150)$ \\
\hline Lettuce & 363 & $\begin{array}{l}\text { Non-fertilized soil } \\
\text { without biochar }(0)\end{array}$ & Non-fertilized soil with $50 \mathrm{~g} \mathrm{~kg}^{-1}$ biochar (B50) \\
\hline Lettuce & 139 & \multirow{3}{*}{$\begin{array}{l}\text { Fertilized soil without } \\
\text { biochar (CS) }\end{array}$} & Fertilized soil with $25 \mathrm{~g} \mathrm{~kg}^{-1}$ biochar $(\mathrm{CS}+\mathrm{B} 25)$ \\
\hline Lettuce & 200 & & Fertilized soil with $50 \mathrm{~g} \mathrm{~kg}^{-1}$ biochar $(\mathrm{CS}+\mathrm{B} 50)$ \\
\hline Lettuce & 268 & & Fertilized soil with $150 \mathrm{~g} \mathrm{~kg}^{-1}$ biochar $(\mathrm{CS}+\mathrm{B} 150)$ \\
\hline
\end{tabular}

A two-way ANOVA found no significance in the interaction of the variables (biochar and fertilizer addition) in the all but one of the cases (four plant growth indicators in each of the two lettuce crop cycles). This confirms the findings of Biederman and Harpole [29] who found limited evidence of a synergistic effect when biochar and fertilizers were applied in a meta-analysis of 371 independent studies. A significance in the interaction of the variables was however observed in the case of the above ground biomass of the first lettuce cycle $(\rho=0.001)$. The general lack of significance in the interaction suggests that biochar did not influence the effect of the organic fertilizer on plant growth, and vice versa, although the fertilizer addition and biochar addition to the soil alone were separately highly influential on the plant growth indicators.

In fertilized soils biochar addition led to a smaller increase in plant growth compared to biochar addition to non-fertilized soils (Table 3). A higher biochar application rate to fertilized soils is therefore required to see the same increase in the measured variables (compared to non-fertilized soils). To achieve a doubling of the number of leaves in each plant in the fertilized soils for example, an addition of $150 \mathrm{~g} \mathrm{~kg}^{-1}$ was required, while in the non-fertilized soils, an addition of only $50 \mathrm{~g} \mathrm{~kg}^{-1}$ of biochar was required.

The degree of above ground biomass (yield) increase with biochar addition was not maintained across all crop cycles. The difference between "0" and B50 was greatest: 903\%, from $3.53 \mathrm{~g}$ to $31.85 \mathrm{~g}$ in the first crop cycle and lowest in the third crop cycle, which showed a much smaller, but still a large difference: $363 \%$. The decline of the yield effect could be a consequence of the depletion of soil nutrients provided by the biochar. Due to the short cropping cycle (in total only 78 days in the 
substrate), the effect of biochar addition could be more pronounced than if longer cycles were used. Both lettuce and cabbage showed the same general response to biochar addition (Figure 2). Optimal soil $\mathrm{pH}$ for lettuce growth is between $\mathrm{pH}$ 6.0-7.0 and for cabbage, 6.0-7.5, and for absolute minimum and maximum growing conditions, $\mathrm{pH} 4.2-7.5$, and 5.3-8.0 respectively [30,31]. Therefore the effect of biochar on $\mathrm{pH}$ is likely to explain increased plant growth, particularly in the case of cabbage, which is more susceptible to acidic conditions [30,31]. Factors other than soil amendment and nutrient status, may have limited plant growth in the pot trials. The survival of only one cabbage plant out of 9 plants in the " 0 " treatment is unexplained; however an insect infestation was observed, and although a number of factors can contribute to plant death, a smaller plant may be more susceptible to attack by insects. The monthly maximum ambient air temperature for the duration of the experiment was between $35-38{ }^{\circ} \mathrm{C}$ [32] which is beyond the optimal range for growth of lettuce (up to $21^{\circ} \mathrm{C}$ ) [31] and cabbage (up to $22^{\circ} \mathrm{C}$ ), and also beyond the absolute maximum range for lettuce $\left(30{ }^{\circ} \mathrm{C}\right.$ ) and cabbage $\left(34{ }^{\circ} \mathrm{C}\right)[30]$, and as such may have negatively affected the plant growth, though this effect would have been the same for all treatments. The increased water holding capacity of biochar [22] may have contributed to reducing wilting [25] in these high temperatures, where evapotranspiration is high, though experimental measurements such as XSF would be necessary to verify such potential effects.

\section{Conclusions}

Rice-husk biochar applied at rates between $50-150 \mathrm{~g} \mathrm{~kg}^{-1}$ in pot trials led to a highly positive effect on lettuce and cabbage growth both with and without local organic fertilizers in a sandy, acidic soil typical for Cambodia. This suggests that RHC has important potential benefits for both subsistence and commercial agriculture. When incorporated into soil substrate in pot trials, biochar and local organic fertilizers altered the soil physical structure (bulk density) and modified the soil chemical properties ( $\mathrm{pH}, \mathrm{CEC}$ and nutrient supply) and the impact extended over three cropping cycles. The lettuce (first crop) displayed proportionally greater gains in productivity (relative to the same crop grown in non-fertilized soil) than the same crop in the third cycle.

In order to maintain benefits to plant growth, it is likely that further re-application of biochar may be necessary. The quantities of biochar application in this trial were equivalent to field rates of up to $167 \mathrm{Mg} \mathrm{ha}^{-1}$, which may not be feasible economically, practically and logistically. However, such rates are credible in a raised-bed horticultural context or in vegetable growing using grow-bags, etc. to which our study is more directly relevant. The present results need to be reproduced under a wider range of growing conditions - and on a large-scale since the maximum advisable additions remain unclear. Nevertheless, it is an important finding that at this high level of application, the RHC did not reduce vegetable growth relative to the control, even in the case where additional organic fertilizer was not also added. This tends to suggest that nitrogen sorption by the rice husk char did not reduce the availability of nitrogen to the plants.

In conclusion, the hypothesis that the addition to soil of the rice husk biochar can be a suitable use of available RHC with attendant agronomic benefits for vegetable production has been supported, especially when other organic amendments can be incorporated into the soil alongside the biochar. It is now necessary for the experiment to be extended to the field-scale in order to test whether the pot-trial results can be reproduced. 


\section{Acknowledgments}

This project was undertaken as part of the BIOCHARM (Biochar for Carbon Reduction, Soil Management and Sustainable Agriculture) project funded by the Asia Pacific Network for Global Change (APN), University of Edinburgh, through an EPSRC Science and Innovation award, and Carbon Captured Ltd. Thanks go to all the staff at the research farm, in particular Vicheth Srin for taking care of the plants, and Tankeo Vichida for translating. We would like to thank Valentini Pappa, Rebecca Rowe and Miranda Prendergast-Miller for comments on the manuscript and Peter Anderson for undertaking the chemical analysis. In addition, four anonymous reviewers made valuable comments on earlier versions of this paper.

\section{References}

1. Shackley, S.; Carter, S.; Knowles, T.; Middelink, E.; Haefele, S.; Sohi, S.; Cross, A.; Haszeldine, S. Sustainable gasification-biochar systems? A case study of rice-husk gasification in Cambodia Part I: Context, chemical properties, environmental and health and safety issues. Energy Policy 2012, 42, 49-58.

2. Shackley, S.; Carter, S.; Sims, K.; Sohi, S. Expert perceptions of the role of biochar as a carbon abatement option with ancillary agronomic and soil-related benefits. Energy Environ. 2010, 22, $167-187$.

3. Shackley, S.; Carter, S.; Knowles, T.; Middelink, E.; Haefele, S.; Haszeldine, S. Sustainable gasification-biochar systems? A case-study of rice-husk gasification in Cambodia, Part II: Field trial results, carbon abatement, economic assessment and conclusions. Energy Policy 2012, 41, 618-623.

4. Sokchea, H.; Borin, K.; Preston, T. Effect of biochar from rice husks (combusted in a downdraft gasifier or a paddy rice dryer) on production of rice fertilized with biodigester effluent or urea. Livest. Res. Rural Dev. 2013, 25, Article No. 4. Available online: http://www.lrrd.org/lrrd25/1/ sokc25004.htm (accessed on 23 January 2013).

5. Lehmann, J.; Gaunt, J.; Rondon, M. Bio-char sequestration in terrestrial ecosystems-A review. Mitig. Adapt. Strategies Glob. Chang. 2006, 11, 403-427.

6. Asai, H.; Samson, B.K.; Haefele, S.M.; Songyikhangs, K.; Homma, K.; Kiyono, Y.; Inoue, Y.; Shiraiwa, T.; Horie, T. Biochar amendment techniques for upland rice production in Northern Laos. 1. Soil physical properties, leaf SPAD and grain yield. Field Crops Res. 2009, 111, 81-84.

7. Hammond, J.; Shackley, S.; Prendergast-Miller, M.; Cook, J.; Buckingham, S.; Pappa, V. Biochar Field Testing in the UK: Outcomes and Implications for Use. Carbon Manag. 2013, in press.

8. Rice Production in Cambodia; Nesbitt, H.J., Ed.; International Rice Research Institute: Manilla, Philippines, 1997; pp. 15-29.

9. Shackley, S.; Sohi, S.P. An Assessment of the Benefits and Issues Associated with the Application of Biochar to Soil; Report to the Department for Environment, Food and Rural Affairs and the Department of Energy and Climate Change: London, UK, 2010; pp. 14-132. 
10. International Biochar Initiative (IBI), Standardized Product Definition and Product Testing Guidelines for Biochar that is Used in Soil, International Biochar Initiative 2012. Available online: http://www.biochar-international.org/sites/default/files/guidelines_for_biochar_that_is_used_in_ soil_final.pdf (accessed on 21 January 2013).

11. European Biochar Certificate (EBC) Guidelines for a Sustainable Production of Biochar, Version 4.5; Delinat Institut and Biochar Science Network: Ayent, Switzerland, 2013. Available online: http://www.european-biochar.org/biochar/media/doc/1358641517626.pdf (accessed on 21 January 2013).

12. Sohi, S.P. Appendix 1. Analysis of scientific studies published on the function of char, its quantification, and its stability in soil. In An Assessment of the Benefits and Issues Associated with the Application of Biochar to Soil; Shackley, S., Sohi, S.P., Eds.; A Report to the Department for Environment, Food and Rural Affairs and the Department of Energy and Climate Change: London, UK, 2010; pp. 1-4.

13. Jeffery, S.; Verheijen, F.G.A.; van der Velde, M.; Bastos, A.C. A quantitative review of the effects of biochar application to soils on crop productivity using meta-analysis. Agric. Ecosyst. Environ. 2011, 144, 175-187.

14. Verheijen, F.G.A.; Jeffery, S.; Bastos, A.C.; van der Velde, M.; Diafas, I. Biochar Application to Soils-A Critical Scientific Review of Effects on Soil Properties, Processes and Functions; Office for the Official Publications of the European Communities: Luxembourg, 2009; EUR 24099 EN, p. 61 .

15. Haefele, S.; Konboon, Y.; Wongboon, W.; Amarante, S.; Maarifat, A.; Pfeiffer, E.; Knoblauch, C. Effects and fate of biochar from rice residues in rice-based systems. Field Crops Res. 2011, 121, 430-441.

16. Shackley, S.; Sohi, S.; Ibarrola, R.; Hammond, J.; Mašek, O.; Brownsort, P.; Haszeldine, S. Biochar as a Tool for Climate Change Mitigation and Soil Management. In Encyclopedia of Sustainability Science and Technology; Meyers, R., Ed.; Springer: New York, NY, USA, 2012; pp. 183-205.

17. Lehmann, J. Bio-energy in the black. Front. Ecol. Environ. 2007, 5, 381-387.

18. Glaser, B.; Lehmann, J.; Zech, W. Ameliorating physical and chemical properties of highly weathered soils in the tropics with charcoal—A review. Biol. Fertil. Soils 2002, 35, 219-230.

19. Chan, K.Y.; Van Zwieten, L.; Meszaros, I.; Downie, A.; Joseph, S. Agronomic values of greenwaste biochar as a soil amendment. Aust. J. Soil Res. 2007, 45, 629-634.

20. Saarnio, S.; Heimonen, K.; Kettunen, R. Biochar addition indirectly affects $\mathrm{N}_{2} \mathrm{O}$ emissions via soil moisture and plant N uptake. Soil Biol. Biochem. 2013, 58, 99-106.

21. Zavalloni, C.; Alberti, G.; Biasiol, S.; Vedove, G.D.; Fornasier, F.; Liu, J.; Peressotti, A. Microbial mineralization of biochar and wheat straw mixture in soil: A short-term study. Appl. Soil Ecol. 2011, 50, 45-51.

22. Case, S.J.; McNamara, N.P.; Reay, D.S.; Whitaker, J. The effect of biochar addition on $\mathrm{N}_{2} \mathrm{O}$ and $\mathrm{CO}_{2}$ emissions from a sandy loam soil-The role of soil aeration. Soil Biol. Biochem. 2012, 51, $125-134$. 
23. FAO. Food and Agriculture organization of the UN World soil resources online. Land and Water development division. WRB Map of World Soil Resources, 2002 updates. Available online: http://www.fao.org/ag/agl/agll/wrb/soilres.stm (accessed on 1 July 2010).

24. Bell, R.W.; Seng, V. Rainfed lowland rice-growing soils of Cambodia, Laos, and North-east. Thailand; ACIAR Proceedings No. 116e. In Water in Agriculture; Seng, V., Craswell, E., Fukai, S., Fisher, K., Eds.; Australian Centre for International Agricultural Research(ACIAR): Canberra, Australia, 2004; pp. 161-173.

25. Mulcahy, D.N.; Mulcahy, D.L.; Dietz, D. Biochar soil amendment increases tomato seedling resistance to drought in sandy soils. J. Arid Environ. 2013, 81, 222-225.

26. Hilber, I.; Blum, F.; Leifeld, J.; Schmidt, H.P.; Bucheli, T. Quantitative Determination of PAHs in Biochar: A Prerequisite To Ensure its Quality and Safe Application, J. Agri. Food Chem. 2012, 60, 3042-3050.

27. Hale, S.; Lehmann, J.; Rutherford, D.; Zimmerman, A.; Bachmann, R.; Shitumbanuma, V.; O'Toole, A.; Sundqvist, K.; Arp, H.; Cornelissen, G. Quantifying the total and bioavailable polycyclic armoatic hydrocarbons and dioxins in biochar. Environ. Sci. Technol. 2012, 46, 2830-2838.

28. Somtrakoon, K.; Chouychai, W. Phytotoxicity of single and combined polycyclic aromatic hydrocarbons toward economic crops. Russian J. Plant Physiol. 2013, 60, 139-148.

29. Biederman, L.A.; Harpole, W.S. Biochar and its effects on plant productivity and nutrient cycling: A meta-analysis. GCB Bioenergy 2013, 5, 202-2014; doi:10.1111/gcbb.12037. Available online: http://onlinelibrary.wiley.com/doi/10.1111/gcbb.12037/full (accessed on 21 January 2013).

30. Food and Agriculture Organization of the UN Ecocrop data sheet-Brassica chinensis. http://ecocrop.fao.org/ecocrop/srv/en/dataSheet?id=547 (accessed on 27 September 2010).

31. Food and Agriculture Organization of the UN Ecocrop data sheet-Lactuca sativa. Available online: http://ecocrop.fao.org/ecocrop/srv/en/dataSheet?id=1313 (accessed on 27 September 2010).

32. Wunderground: Siem Reap Airport. Available online: http://www.wunderground.com/ (accessed on 4 July 2010).

(C) 2013 by the authors; licensee MDPI, Basel, Switzerland. This article is an open access article distributed under the terms and conditions of the Creative Commons Attribution license (http://creativecommons.org/licenses/by/3.0/). 